\title{
Porous Borders and Increasing Human Trafficking in West Africa: Issues and Challenges
}

\author{
Omolara Akinyemi \\ E-mail: larvickky02@gmail.com
}

Received: July 27, 2019 Accepted: September 7, 2019 Published: September 28, 2019

doi:10.5296/ijssr.v7i2.15537 URL: http://dx.doi.org/10.5296/ijssr.v7i2.15537

\begin{abstract}
The porous nature of West Africa's borders, which owes its origin to the hasty way the colonialists carved up the African continent as well as the nature of their management by post-colonial states, has become serious issue in human trafficking, money laundering and other related crimes. Thus, one of the major consequences of porous borders in West Africa today is the rise of trans-border crimes. The problem lies in the complexity of these organizations and their activities, the global penetration and the threat they pose to democracy and legitimate economic development. Some of these trans-border crimes include: the narcotics trade and money laundering, illegal migration and people's trafficking, smuggling (small and light weapons, food items, vehicles) among others. Nevertheless, the never-ending business of trafficking in humans across borders today is organized by individuals and groups, it is colluding with government officials and its devastating impact on exasperated individual victims is the major concern of this study. Data obtained from primary and secondary sources (literature review and content analysis) were deployed to carry out the study with an analytical and narrative historical method. The study concludes that human trafficking can be reduced to the barest minimum in the region, if West African human and material resources are combined together to expand regional capacity for border security.
\end{abstract}

Keywords: Borders, Border Crimes, Human Trafficking and Security 


\section{Introduction}

The end of the Cold War saw the emergence of a new phenomenon in the international community; featuring among the list of such evolving issues is the phenomenon of porous borders and the recurring crimes associated with it. This poses serious threats to global peace and security. The dimensions and momentum of trans-border crimes have increased with the emergence of globalization (Simon, 2011). This also encouraged the opening of borders among the countries of the world. Thus, countries with varying degrees of development in socio-economic, political and cultural spheres are merged together in one form of regional arrangement or the other and this has further helped in facilitating the activities of transnational criminal activities (Opanike \& Aduloju, 2015). Undoubtedly, the porosity of West Africa borders can be traced, first the colonialist in their partition of African continent and second the administration and management of the borders by the colonialist states even after independence. It should be noted that, prior to independence the original motive in Africa was not the creation of boundary but to establish a sphere of influence mainly for economic and political purpose. Indeed, the colonial demarcation of boundaries with no respect to the socio-cultural background of the people in Africa explains the reason why their tribal brothers and sisters are scattered across the borders.

However, one of the major consequences of porous borders in West Africa today is the rise of trans-border crimes. The problem lies in the complexity of these organizations and their activities, global penetration and the threat they pose to democracy and legitimate economic development. These organizations clearly undermine the concept of the nation state (Shelley, Picarelli \& Corpora, 2003). Some of these trans-border crimes include: the narcotics trade and money laundering, illegal migration and people's trafficking, smuggling (small and light weapons, food items, vehicles) among others. Nevertheless, the never-ending business of trafficking in humans across borders today is organized by individuals and groups, colluding with government officials and its devastating impact on exasperated individual victims is the major concern of this study. It is important to note that in the recent years, the West African sub-region has been experiencing high increase in smuggling of migrants and trafficking in persons. Although, the awareness of this menace can be attributed to media, nongovernmental organizations (NGOs) especially in Nigeria, Togo and Benin Republic in the late 1990s. This is evident in the report of one of the Nigerian NGOs known as Constitutional Rights Project. This report places emphasizes on the increase rate of child trafficking within and outside Nigeria. In a similar vein, a Togolese NGO known as WAO-Afrique gives report of children from rural areas smuggle to urban centres as domestic servants in Lome as well as to Gabon (Adepoju, 2005). Another dimension to this menace is that parents or guardians of trafficked children are sometimes unaware of the exploitation or inhuman treatment their wards are subjected to. Leading credence to this argument is report by the United Nations Children's Fund (UNICEF, 2003) that a large number of Africans recognized trafficking as a problem and children are more vulnerable than women. While, the report by the United Nations Office on Drugs and Crimes (UNODC Report, 2006) reports that $81 \%$ of human beings in West African countries are involve in trafficking. The report notes further that this percentage are majorly traffic for sexual exploitation involving women are girls. Therefore, it 
is of surprise that out of the gender or traffickers information provided by countries in the region, women top the largest proportion of traffickers. Notably, aside from women being traffic for sexual exploitation, forced labour is another reason for trafficking in person. Although, forced labour is frequently not reported than for sexual exploitation. In fact, no country in West Africa is free from this act of trafficking as countries of source, transit, destination or a combination of all three.

\section{Review of Literature}

\subsection{The Nature of West African Borders}

There is no doubt that the West African borders are indeed porous. This is also corroborated by Okumu's writing that West African borders have become a safe haven for smugglers to penetrate due to the nature of West African borders. To him, the revenues generated from border crossing points have been used to perpetrate other criminal activities and social problems such as prostitution (Okumu, 2011). However, Okumu's argument is one sided on the porosity of border as a rationale for human trafficking because he fails to acknowledge other push and pull factors for the rise of human trafficking. While, Julins (2002) and Akinyemi (2013) note that globalization is the major cause of trans-border crimes. To them, the advent of globalization has increased the rate of criminals' activities and is perceived as an opportunities of gaining greater rewards outside their traditional domain. Julins further links that the increase of border criminal activities to high levels of income in Western Europe and North America. Thus, creating an opportunity for illicit trade of all kind such as drugs, currency, prostitution and many more (Julins, 2002).

On the contrary, De Andres is of the opinion that criminal trade is both sided, as countries export and import crimes as well (De Andres, 2008). Also, in 2004 UN Secretary-General gives a report on ways to combat sub-regional and cross border crimes in West Africa. It is based on this report the following problems were identified: the continued weakening of the security sector, proliferation of roadblocks, explosive remnants of war (ERW), mass refugee movements and forced displacement and human right abuses in the sub-region. In response to managing the mayhem of cross-border crimes Wafula Okumu concludes that these realities requires urgent attention and need for adequate mechanism for border management as well as joint effort to deal with the problem in the spirit of regional and continental integration (Okumu, 2011). Indeed, the rate of human trafficking cannot be overemphasized in West Africa, as young children and women are majorly transit from rural to urban centres especially from Mali, Benin, Burkina Faso, Togo, and Ghana to Cote d'Ivoire's to destination countries like Nigeria and Gabon. This is done through adduction of children, buying of children from poor parents, bonded placement of children as reimbursement for debt, placement for a token sum for specified duration or for gift items and enrolment for a fee by an agent for domestic work at the request of children's parents (Veil, 2008). In a similar vein, Aderanti Adepoju notes that Ghana is a transit route for Nigerian women trafficked to Italy, Germany, and Netherlands for commercial sex. This is evident in the high number of women and children trafficked to neighboring countries for forced labour and prostitution. While other women are trafficked to Europe as sex workers. To him, Senegal is both a source and 
transit country for women trafficked to Europe, South Africa, and Gulf States for illicit work. (Adepoju, 2005). However, one major reason for this is the violent conflict in the region resulting in women the warring countries such as Liberia and Sierra Leone forced to prostitution in Mali. The implication here is that Mali is sometimes used as a transit country of women from Anglophone African countries to Europe.

Unarguably, Africa is a region of migration, in which people often move voluntarily or involuntarily as result of violent conflict, civil war, poverty or environmental factors. However, due many problems such as economic or political, the region has not paid adequate attention to the issues of trafficking. Thus, the problem of human trafficking in the region has been a domino effect that cut across other sub-regions. It is based on the forgoing that UNICEF conducts a research both West and Central Africa on the rise of human trafficking in these regions. The study identifies poverty as a "major and ubiquitous" causal factor behind human trafficking, in which between $33 \%$ and $73 \%$ of the general population lives on less than 1 US \$ for a day (UNICEF Report, 2003). Although, this problem is related to some factors such as "push and pull" factors. The push factors forced individuals to move from a country to other in search of a better life elsewhere. This factor includes economic, environmental problems, poverty as well as unemployment (Salah, 2001). This is also compounded by various economic policies leading to economic decline and debt as the case may be. This in turn leads to political instability in many countries in the region. While the pull factor can be divided into two main causes. First, is the demand for cheap labour and high demand for paid sex in destination countries. In these main causes, children and women are the most vulnerable due to their weakness and ignorance. Thus, they are easily influenced and manipulated. This is because children can be forced to work for long hours with less food, poor accommodation and no benefits. (ILO-IPEC Report, 2002).

While Salah gives a detailed explanation on the historical and cultural patterns of migration and the placement of children outside the home. He gives example of child fosterage, sending children to live with extended family or friends to be educated, trained or to work in order to foster unity and solidarity in the family as another contributing factor to human trafficking in West Africa. Even UNICEF (2002) reports that parents who are financially incapacitated give their children out to traffickers for job, education or vocational training. It is on this note that the US Department of State in year 2000 produced a 'Trafficking in Persons Report' rating different countries in their effort to combat trafficking in persons. In 2004, most of the West African countries were in Tier 2 or below except Ghana (Tier 1). The link between effort in combating trafficking and aid from the US government has encouraged West African governments to examine the issue.

This simply means that Mali is sometimes use as a transit country of women from Anglophone African countries to Europe. From this stand point, this study will wrap up its review by acquiescing with the analysis made by UNICEF (UNICEF Report, 1998). The report gives a detailed explanation on how these children are recruited through the network of agents and ignorance of the victims. Furthermore, UNICEF notes that some countries in the region such as Benin, Ghana, Nigeria, Mali, Burkina Faso, Mauritania, and Togo as the main suppliers of domestic workers to Equatorial Guinea, Côte d'Ivoire, and Nigeria. Most of these 
children are recruited through the network of agents to work as domestic servants in informal sectors or on plantations. They however blamed parents, which are often compelled by forces of poverty and ignorance for releasing their children, with hope that the illicit work will raise their living standards. Unfortunately, some of these children are used as slave, exploited and paid below living wages. Therefore, it has been considered that border security has a direct relationship with stability and development in the sub region. Increase in the poverty rate in the sub-region has motivated several individuals to search for greener pastures elsewhere thus, being trafficked in the process. Hence, the continuous silence about the rectification of border porosity in the sub-region has greatly contributed to the unending mayhem of trafficking in humans.

However, as regards the subject matter, adequate research has not been done on it in West Africa. Although, the limited research little tends to suggest that West Africa is not only a region of origin, but also contains countries of transit and destination. Furthermore, is existence of internal trafficking, from domestic to urban areas within a country borders, and external trafficking to other African countries, the Middle East and Europe in search a better living. Hence, the routes used for trafficking are dependent on many factors such as the availability of transportation and communication. Another focus on West Africa research is on two particular routes and forms of exploitation in West Africa. The first is the adolescent boys from Mali and Burkina Faso transported to work on farms in Ivory Coast, and younger girls from Benin and Togo are taken to Ghana and Nigeria to work as domestic servants.

\subsection{Human Trafficking in the West Africa Area: Figures and Cost}

Interestingly, this study also identified with Laetitia Veil writing on the different types of child trafficking in West Africa. This ranges from, abduction of children, buying of children from poor parents, bonded placement of children as reimbursement for debt, placement for a token sum for specified duration or for gift items, and enrolment for a fee by an agent for domestic work at the request of the children's parents. Sometimes the parents of the victims are deceived, with the sole aim that their children would be enroll to school. (Veil, 2008). Even, the Human Rights Watch of 2003, reports that many Nigerian children are trafficked to Europe, the Gulf States and some African countries as domestic workers and sexual exploitation in European countries. In sum, poverty is a major contributing factor to human trafficking in many of the West African States.

Similarly, Aderanti Adepoju places emphasizes on Ghana as the transit route for Nigerian women trafficked to Italy, Germany, and the Netherlands for commercial sex. To him, both Ghanaian women and children are sometimes trafficked to neighboring countries for forced labour amd prostitution. While other women are trafficked to Europe as sex workers. According to Aderanti Adepoju, Senegal is both a source and transit country for women trafficked to Europe, South Africa, and the Gulf States for the illicit work. Likewise, Senegal is a destination country for children trafficked from Mali and Guinea Conakry (Adepoju, 2005). Aderanti also identifies violent conflict as a contributing factor in the region. This is evident in women from the warring countries such as Liberia and Sierra Leone forced to prostitution in Mali. This simply means that Mali is sometimes use as a transit country of 
women from Anglophone African countries to Europe. One method employed by the syndicates is by obtaining all the necessary travel documents for the women and link them with brothels abroad. Undoubtedly, the victims are faced with all kind of challenges, sometimes get stranded in countries such as Italy, Morocco for many years. While, some are detained or died on the way.

From this stand point, this study will wrap up its review by acquiescing with the analysis made by UNICEF (UNICEF Report, 1998). The report gives a detailed explanation on how these children are recruited through the network of agents and ignorance of the victims. Furthermore, UNICEF notes that some countries in the region such as Benin, Ghana, Nigeria, Mali, Burkina Faso, Mauritania, and Togo as the main suppliers of domestic workers to Equatorial Guinea, Côte d'Ivoire, and Nigeria. Most of these children are recruited through the network of agents to work as domestic servants in informal sectors or on plantations. They however blamed parents, which are often compelled by forces of poverty and ignorance for releasing their children, with hope that the illicit work will raise their living standards. Unfortunately, some of these children are used as slave, exploited and paid below living wages. Therefore, it has been considered that border security has a direct relationship with stability and development in the sub region. Increase in the poverty rate in the sub-region has motivated several individuals to search for greener pastures elsewhere thus, being trafficked in the process. Hence, the continuous silence about the rectification of border porosity in the sub-region has greatly contributed to the unending mayhem of trafficking in humans.

\section{Methods}

The specific type of survey research design favoured for this study is the descriptive survey, which allows for the collection of data for the purpose of a systematic description of nature, the features as well as obtaining a general overview of the phenomena being studied. This involved the use of primary and secondary sources of data collection. The primary source of data involved in-depth interviews (IDI), conducted to demonstrate the nexus between porosity of borders and upsurge of human trafficking in West Africa. Descriptive survey design was suitable for obtaining the general overview of factors that aided the increase of human trafficking in West Africa. This was to ensure the reliability and validity of the data collection. In light of the above, study area covered the West African sub-region comprising 15 ECOWAS member states with their diverse language backgrounds. However, since all the countries of the sub-region cannot be covered, Nigeria, Ghana, Benin Republic and Niger Republic of the ECOWAS member states were purposively selected for the actual research study area. Nigeria and Ghana represent the Anglophone countries while Benin Republic and Niger Republic represent the francophone countries in the sub-region. The study purposively selected 20 respondents drawn from victims of trafficking in Nigeria and Ghana, female children trafficked in Benin Republic, victims of trafficking at the Organisation Internationale pour les Migrations (OIM) in Niger Republic, Immigration and custom officers at Nigeria-Benin border, Ministry of women affairs in Nigeria and Ghana and Ministries in charge of children's welfare in Benin and Niger Republic were consulted. While secondary data was sourced from journals, textbooks, newspaper publications, documents from non -international organization such as WOTCLEF, and extracts from ESPAM as well as other 
internet sources for the attainment of relevant information on human trafficking in borders in West Africa. Data obtained from field work was triangulated with evidence from literature to achieve the objective of this study.

\section{Findings}

From the data gathered, the study revealed that the main targets of trafficking in West Africa are mainly children, women and economic migrants. Most of the respondents especially from Nigeria claimed ignorance of this acts, while some children trafficked from Benin Republic to Nigeria became a victim of commodification due to poverty. Thus, this is known as children exploitation and forced recruitment. It is of no surprise that the International Labour Report of 2002 notes that child trafficking in West Africa could be traced to deteriorating economic situation, leading to families giving up their children as result of poverty, unemployment and many more (ILO Report, 2002). Another form of trafficking identified by the respondents is forced marriages, domestic work, forced recruitment of child soldiers and many more.

Furthermore, trafficking of women in West Africa cannot be overemphasized. This is evident in forced marriages and prostitution of women and girls. This is also report by Nigerian National Agency for the Prohibition of Traffic in Persons (NAPTIP) that more than 50,000 girls are being trafficked to work in the sex industry in Italy (OHCHR Report, 2005). To some of the respondents repatriated back from Libya on their journey to Italy at Agadez, Niger Republic, revealed that they became a victim of traffickers due to poverty, rural-urban migration induced by globalization, broken homes and peer influence. However, some respondents claimed ignorance that they were sold by their parents due to poverty. Therefore, they end up offering sexual services in brothels or as domestic servants. This argument also resonated in Human Rights Watch Report of 2003, women had assumed sole responsibility in many families today. It is on this basis that women are forced to migrate in search of employment to improve their families' wellbeing. It is important to note that some of them are exposed to all kinds of diseases ranging from Sexually Transmitted Diseases or HIV AIDS. It is also confirmed my Human Right Watch of 2003 reports that $80 \%$ of women in Lome were tested positive to HIV infection (Human Rights Watch Report, 2003). Furthermore, Aderanti in his writing pointed out that, in some West African states, the belief that having sexual intercourse with a young girl diminishes the risk of contracting HIV/AIDS has also increased demand for young sex workers, and unscrupulous criminals are cashing in on this situation by trafficking young girls to the country (Aderanti, 2005) While some are also victims of rape, tortured, and subjected to other forms of inhumane physical abuse by clients and traffickers (Pearson, 2002). It is on this argument above that Afonja in his writing argued that many Nigerian girls in Italy are sometimes battered by their clients making them to seek protection from the Italian Government, NGOs, and the church (Afonja, 2001).

Another striking factor is the cross border linkages as well as the porous nature. In the late nineteenth century when the Europeans powers redrew the national boundaries arbitrarily, ethnic groups became divided. This arbitrary nature has created the cross border linkage (Eveslage, 2013). Therefore, a background study of this linkage can be traced to the history 
of the ethno-linguistic relationship between the peoples such as Nigeria and Niger Republic in the north as well as Nigeria and Benin Republic. This problem had allowed the influx of all kinds into many countries in the sub-region. In the light of the above respondents from border officials reveals traffickers take advantage of lack of proper security, effective documentation and identity systems especially in Nigeria and Ghana as an escaping route for the traffickers. This is evident in the acquiring of visas through illegal means or through falsification of documents as well as with the collaboration of unscrupulous immigration officers. Moreover, is the free movement of persons of the Economic Community of West African States (ECOWAS) that facilitates easy migration into other parts of West Africa; and the weak capacity of these states as well as the apparent unfavourable socio-economic conditions of these countries.

The reality is that the West African borders are not properly manned by military personnel. According respondents at the Nigerian custom office, the traffickers live around the borders and familiar with the routes more than the attached military personnel who have the sole responsibility of manning the border. It is of no surprise that there is an open ground for migration as there is little or no obstacle and restriction to the inflow of people and goods in the region. This in turn leads to indiscriminate and easy movements of people into territories of neighboring countries. Therefore, the porosity of border has enhanced the illegitimate economic interactions such as human trafficking, drug trafficking and many more. In fact, some of the respondents at the IOM at Agadaz, Niger Republic argued that the porous nature of West African borders made their movement possible. In this regard, some of the victims cross Nigerian border to Niger Republic without having the necessary travelling documents, with the intention of crossing Niger Republic to Libya and later to Europe.

Apparently, the porous nature of African borders and the lack of proper security and identity systems, encourage the continuous actions of human trafficking. Of the countries in West Africa, Nigeria is one that has the largest land space unmanned, unreached, unused, or without a functional governmental presence. This is also compounded by the high level of poverty in the neighbouring countries. This is turn made Nigeria, a hot spot of human trafficking activities, where traffickers are taking advantage of lack of effective documentation, security and identity systems. Visas are acquired through illegal means or through falsification of documents often in collaboration with immigration officials. In addition, lapses in border security and ineffective identification systems in Ghana and Nigeria have availed to traffickers, many hidden recruitment points for trafficking activities. In rural areas where there is poverty and lack of education, children are often recruited from rural zones to urban areas. It is important to note that the final destination of trafficked individuals is dependent on the purpose of their exploitation. Nonetheless, in the case of most female victims, Italy is the preferred target from Nigeria. As such, individuals who were unable to reach Europe often found themselves stranded in North Africa. In cross-border child trafficking, Benin, Ghana, Nigeria, and Togo are the main countries of origin from which child domestic labour is exported to the main urban centers of countries such as Congo, Equatorial Guinea, Cote d'Ivoire, Gabon and Nigeria. (UNICEF Report, 1998). It is of no surprise that children are often times trafficked through the borders. And this is owing to its 
poor management and weak security along the borders. For instance, four trafficking routes were identified from northern Nigeria. This includes those leaving from Kebbi or Sokoto travel to the Republic of Benin, on to Niger, Ghana, Senegal and move on the destinations as Libya, Algeria or Morocco. These are transit countries for the destinations in the Middle East or Europe.

\section{Conclusion}

This paper has been able to draw a connection between the porosity of West African borders and its contribution to the ills of human trafficking. In this study, the impacts of border insecurity have been systematically assessed and the trends and patterns of trafficking in humans. Ironically, West African borders are not free for traded goods to cross but easy for trans-border crimes due to the poor management. In other words, the borders are free for contrabands and all kind of criminal activities without fear. This is due to poor management and insecurity at the West African borders. Although, there are a number of concrete measures that can transform borders for lives and property to be adequately secure. Thus, this phenomenon however constitutes a great challenge to good governance for the entire region.

In view of this, the only feasible option for eradicating human trafficking in the foreseeable future is to cooperate and pool West African human and material resources in order to expand regional capacity for border security. The training and re-training of border officials for effective management of the borders. Additionally, combatting the issue of trafficking requires the strengthening and universal ratification of anti-trafficking protocols such as the UN anti-trafficking protocol by all West African countries and domestication of these laws in respective countries.

\section{References}

Adepoju, A. (2015). Review of Research and Data on Human Trafficking in Sub-Sahara Africa. International Migration, 43(1-2), 75-98.

Afonja, S. (2001). An Assessment of Trafficking in Women and Girls in Nigeria Ile Ife. Unpublished mimeo.

Akinyemi, O. (2013). Globalisation and Nigeria Border Security: Issues and Challenges. International Affairs and Global Strategy, 11.

ESAM. (1999). Child Trafficking in Benin and Gabon, Research Report, 1998-1999. Retrieved February 20, 2019, from http://www.en.horyou.com/org/esam-enfants-solidaires-d-afrique-et-du-monde

Eveslage, B. (2013). Clarifying Boko Haram's Transnational Intentions. Perspectives on Terrorism, 7(5), 50.

Human Rights Watch. (2003). "Borderline Slavery: Child Trafficking in Togo", HRW, New $\begin{array}{lllll}\text { York. } & \text { Retrieved } & \text { March } & \text { 2019, from }\end{array}$ http://www.hrw.org/reports/2003/togo0403/togo0403.pdf

International Labour Organization (ILO). (2002). Unbearable to the Human Heart: Child 


\section{MInstitute Macrothink $_{\text {Int }}$}

International Journal of Social Science Research

ISSN 2327-5510

2019, Vol. 7, No. 2

Trafficking and Action to Eliminate It. ILO, Geneva. Retrieved February 18, 2019, from https://www.ohchr.org/Documents/Issues/Trafficking/Dakar_Saddikh_Niass_en.pdf

Julins, O. (August 16-19, 2002). Exploring Strategies for Effective Management of Nigeria Niger Border Security. In Amdii S. et al; The Nigeria-Niger Trans-border Cooperation and Management:: Proceedings of the International Seminar Organised by National Boundary Commission and Niger Boundary Commission.

Okumu, W. (2000). Border Management and Security in Africa. Retrieved January 22, 2019, from http://www/reserchgate.net/-/wafula-border_security/-/bordermanagement

Opanike, A., \& Aduloju, A. (2015). ECOWAS Protocol on Free Movement and Trans-Border Security in West Africa. Civil and legal science, 4.

Pearson, E. (2002). Human Traffic, Human Rights: Redefining Victim Protection, Anti-slavery International. Retrieved March 5, 2019, from http://www.antislavery.org/wp-content/uploads/2017/01/hum_traff_hum_rights_redef_vic_pr otec_final_full.pdf

Salah, R. (2001). Child Trafficking in West and Central Africa: An Overview. Paper presented at the first Pan African Conference on human trafficking organised by Wotclef at the International Conference Centre, Abuja.

Simon, O. E. (2011). Trans-Border Crime and its Socio- Economic Impact on Developing Economies. Journal of Sociology, Soc Anth, 2(3).

U.S. Department of State. (2000). Country Reports on Human Rights Practices cited in Global March Against Child Labour; Worst Forms of Child Labour, Benin. Retrieved February 19, 2019, from http://www.state.gov/j/tip/rls/tiprpt/countries/2018/282614.html

United Nations Commission on Human Rights, Sub-committee on Prevention of Discrimination and Protection of Minorities, Working Group. (1999). Analysis on the problems of child trafficking in West and Central Africa. Retrieved February 27 2019, from https://www.un.org/documents/overview-of-resolutions-by-human-rights-council-UN-Genera 1.pdf

United Nations International Children's Emergency Fund. (1998). The Issue of Child Domestic Labour and Trafficking in West and Central Africa. Retrieved March 6, 2019, from http://www.unicef.org/media/newsnotes/africchildtraffick.pdf

United Nations International Children's Emergency Fund. (July 6-7 1998). Report on the trafficking of child domestic workers, especially domestic girls in the West and Central Africa region, Cotonou, Benin. Retrieved January 22 2019, from https:www.unicef.irc.org/publications/pdf/insight7.pdf

United Nations Office on Drugs and Crimes (UNODC). Crime and drugs as impediments to security and development in Africa: a programme of action, 2006-2010. Retrieved February 28 2019 , from http://www.unodc.org/documents/human-trafficing/ht_reserach_report_nigeria.pdf 


\section{Macrothink}

\section{Copyrights}

Copyright for this article is retained by the author(s), with first publication rights granted to the journal.

This is an open-access article distributed under the terms and conditions of the Creative Commons Attribution license (http://creativecommons.org/licenses/by/4.0/). 